\title{
THE MAIN CHARACTERISTICS OF THE INTERNATIONAL CRIMINAL TRIBUNAL FOR THE FORMER YUGOSLAVIA DURING ITS MANDATE FROM 1993 TO 2017
}

\section{Viona Rashica}

PhD Candidate of Political Sciences, South East European University, Tetovo,

North Macedonia

vr26813@hotmail.com

DOI: $10.2478 /$ seeur-2019-0006

\begin{abstract}
The tradition of international criminal tribunals which started with the Nuremberg and Tokyo tribunals was returned with the International Criminal Tribunal for the former Yugoslavia. As a result of the bloody wars in the territory of the former Yugoslavia in the 1990s, the Security Council of the United Nations decided to establish the ICTY as an $\mathrm{ad}$ hoc tribunal, that was approved by the resolutions 808 and 827 . The main purpose of the paper is to highlight the features of the ICTY during its mandate from 1993 to 2017. For the realization of this research are used qualitative methods, based on the bibliography that is related with international criminal law, with special emphasis with the activities of
\end{abstract}


international criminal tribunals. Furthermore, some data are also collected from the credible internet sources, which have valuable information about the procedures of the ICTY and for the International Residual Mechanism for Criminal Tribunals. The results of the study demonstrate that during its mandate, the ICTY was accompanied with a lot of successes which distinguish it from the other international criminal tribunals. At the same time, the ICTY has also a lot of failures, which have come as a result of various political influences within it. The conclusions of this paper aim to increase knowledge about the activity of the ICTY, by offering important information for its establishment and organs, and for its main successes and failures.

Key words: Yugoslav Wars, United Nations, Security Council, International Criminal Tribunal for the former Yugoslavia.

\section{Introduction}

The paper treats one topic which is about a very important part of international criminal law. The establishment of the international criminal tribunals that exercise direct jurisdiction over persons charged with specified crimes represents a modern legal phenomenon. This phenomenon which was appeared after the Second World War with the Nuremberg and Tokyo tribunals, continued with the International Criminal Tribunal for the former Yugoslavia and the International Criminal Tribunal for Rwanda. The main purposes of the paper are these: To explain individual criminal responsibility in international law and the 
creation of the international criminal tribunals; to specify the factors which contributed in the dissolution of Yugoslavia and resulted with the establishment of the ICTY, to emphasize the main characteristics of the ICTY organs, to classify the main successes and failures of the ICTY, and to describe the role of the International Residual Mechanism for Criminal Tribunals. The research question of the paper is: Was the ICTY successful in the sentencing of accused persons for crimes in the Yugoslav wars? The hypotheses of the paper are these: ICTY can be considered as one of the most successful tribunals in the history of international criminal tribunals; The failures of the ICTY highlight the presence of various political influences within it.

Therefore, to give an answer to the research question and to identify the raised hypotheses, the paper in addition to the abstract, introduction, conclusion, bibliography and the internet sources, consists of eight chapters. The first chapter is about individual criminal responsibility in international law, while the second chapter has information about the creation of the Nuremberg and Tokyo tribunals. The third chapter classifies the external and internal factors which contributed in the dissolution of the federation of Yugoslavia; the fourth one explains the establishment of the ICTY, to continue with the fifth one which has data about the chambers, registry and office of the Prosecutor which were the organs of the ICTY. The sixth and seventh chapters specify the main successes and failures of the ICTY, and the eighth chapter describes the role of the IRMCT. This paper has an explanatory, descriptive, analytical and comparative nature, and for its realization is used qualitative methods, relying in bibliography and the 
credible internet sources that is related with international criminal law, the ICTY and the IRMCT.

\section{Individual criminal responsibility in international law}

International law typically governs the rights and responsibilities of states, while criminal law is paradigmatically concerned with prohibitions addressed to individuals, violations of which are subject to penal sanction by a state. Thus, international criminal law constitutes the fusion of these two legal disciplines (Bantekas \& Nash, 2009, p. 1). When lawyers and specialists talk about international criminal law, they focus on crimes that are also, by and large, gross and systematic violations of human rights like genocide, crimes against humanity and war crimes (Schabas \& Bernaz, 2011, p. 1).

According to the Convention on the Prevention and Punishment of the Crime of Genocide, genocide means any of the following acts committed with intent to destroy, in whole or in part, a national, ethnical, racial or religious group, as such: killing members of the group; causing serious bodily or mental harm to members of the group; deliberately inflicting on the group conditions of life calculated to bring about its physical destruction in whole or in part; imposing measures intended to prevent births within the group; forcibly transferring children of the group to another group ("Genocide - Background," n.d.).

Crime against humanity means any of the following acts when committed as part of a widespread or systematic attack directed against any civilian population, with knowledge of the attack: murder; 
extermination; enslavement; deportation or forcible transfer of population; imprisonment or other severe deprivation of physical liberty in violation of fundamental rules of international law; torture; rape, sexual slavery, enforced prostitution, forced pregnancy, enforced sterilization, or any other form of sexual violence of comparable gravity; persecution against any identifiable group or collectivity on political, racial, national, ethnic, cultural, religious, gender, or other grounds that are universally recognized as impermissible under international law; enforced disappearance of persons; the crime of apartheid; other inhumane acts of a similar character intentionally causing great suffering, or serious injury to body or to mental or physical health (“Crimes Against Humanity - Background,” n.d.).

War crimes are those violations of international humanitarian law (treaty or customary law) that incur individual criminal responsibility under international law. As a result, and in contrast to the crimes of genocide and crimes against humanity, war crimes must always take place in the context of an armed conflict, either international or non-international ("War Crimes - Elements of the Crime," n.d.).

With the probable exception of the crime of aggression with its focus on inter-state conflict, the concern of international criminal law is now with individuals and with their protection from wide scale atrocities (Cryer et al., 2007, p. 1). The rise of individual criminal responsibility directly under international law marks the coming together of elements of traditional international law with more modern approaches to human rights law and humanitarian law, and involves consideration of domestic as well as international enforcement mechanisms (Shaw, 2008, p. 397). 
During the world wars, the brutality, and the number of victims and categories of persons who suffered was increased. These facts have had a significant impact on the issue of responsibility of individuals and organizations for international crimes.

\section{The appearance of international criminal tribunals}

The establishment of international courts that exercise direct jurisdiction over persons accused with specified crimes represents a modern phenomenon. Following their victory in the Second World War, the allied powers (United States of America, the United of Soviet Socialist Republics, France and the United Kingdom) established International Military Tribunals in Nuremberg and Tokyo to judge war criminals from the German and Japanese forces (Bantekas \& Nash, 2009, p. 495). On August 8, 1945, their governments signed an Agreement for the Prosecution and Punishment of War Criminals, known as the London Agreement. Traditional war crimes were generally defined by treaties such as the 1907 Hague Conventions and the 1929 Geneva Conventions (Gallant, 2009, p. 77).

The Nuremberg International Military Tribunal is the first international criminal tribunal, which marks the real starting point for international criminal law. It was created based on the Allied decision of November 20, 1945 and its mandate lasted until October 1, 1946. After almost a year of work, this tribunal sentenced 12 people with death, 3 persons with life imprisonment and 4 persons with imprisonment from 10 to 20 years (Gruda, 2013, p. 152). It should be emphasized that differences between the civil law States (France and the USSR) and their 
common-law counterparts (the UK and USA) on the appropriate procedures for the trial also caused considerable difficulties.

The Tokyo International Military Tribunal was formed for the judgment of Japanese criminals by a proclamation of General Douglas MacArthur (American five-star general and Field Marshal of the Philippine Army) and it was based on the Nuremberg principles. The judgment process began with the submission of the first indictment on April 29, 1946. On September 12, 1948, this tribunal sentenced 5 persons with death, 16 individuals with life imprisonment and 2 persons with imprisonment from 7 to 20 years (Gruda, 2013, p. 153).

Until the early 1990s, it seemed unlikely that the progeny of Nuremberg and Tokyo IMTs would appear soon. However, in response to two conflicts in the 1990s (the Yugoslav wars of dissolution and the Rwandan genocide of 1994) the United Nations revived the idea of international criminal tribunals (Bantekas \& Nash, 2009, p. 512).

\section{The dissolution of the socialist federal republic of Yugoslavia}

In 1952, the federal structure of Yugoslavia consisted of six Republics: Serbia, Croatia, Slovenia, Macedonia, Montenegro and Bosnia and Herzegovina, and two autonomous sub-federal units, Kosovo and Metohija (renamed Kosovo in 1963), and Vojvodina. The dissolution of Yugoslavia was influenced by many factors which can be classified into external and internal factors.

The fall of communism in Eastern Europe began in 1989. The reunification of Germany in 1990 marked a very important step in the 
end of the Cold War and a year later the Soviet Union was dissolved. These events had a major impact on Yugoslavia's political stability because the lack of Soviet threats on the integrity and unity of the Yugoslav state meant that strong impetus for unity and cooperation was abolished. Subsequently, the former communist Eastern European states began to apply democratic and free trade reforms, which resulted with high focus of the Western countries in these states, moving away from Yugoslavia. Minimizing of the economic support caused major crises in the Yugoslav economy.

Marshal Josip Broz Tito, who had been President of Yugoslavia for thirty-five years, died in 1980. In 1981, Albanians of Kosovo wanted to change the status of Kosovo from the autonomous province in the republic, a request that raised the nationalist Serbian voices. In February 1989 and in July 1990, the changes of the Serbian Constitution effectively revoked the legal basis for Kosovo's autonomy within Serbia and the status of Kosovo was returned to that which had in the Yugoslav Constitution of the 1946, although its reintegration into Serbia was opposed by a number of Yugoslav republics, especially from Slovenia (Radan, 2002, p. 200-201). In the dissolution of Yugoslavia contributed also the tensions between Serbs with Croats and Slovenians on the one hand, as well as the tensions of Serbs with Albanians on the other hand, the arrival of Slobodan Milošević at the head of Serbia in 1987, the strong reactions of Croats and Slovenians against the tendencies of Serbia to dominate over other people of Yugoslavia and their preparations for the declaration of their independence (Hoti \& Musliu, 2015, p. 181). In 1990's nationalism had replaced communism as a 
dominant force in the Balkans and resulted with Yugoslav wars, which were the bloodiest wars in Europe since the Second World War.

\section{The establishment of the international criminal tribunal for the former Yugoslavia}

In Europe, World War II was followed by a long and stable period of peace that was interrupted by massive violations of international humanitarian law and human rights in the former Yugoslavia beginning in 1991. In reaction to this situation the UN established the "United Nations Commission of Experts Pursuant to Security Council Resolution 780". The Commission submitted a first Interim Report on the basis of which the Security Council decided to establish an ad hoc International Criminal Tribunal for the former Yugoslavia (Ambos, 2013, p. 19). The establishment of this tribunal was approved by the resolutions 808 (22.02.1993) and 827 (25.05.1993), was amended by the resolutions 1166 (13.05.1998), 1329 (30.11.2000), 1411 (17.05.2002), 1431 (14.08.2002), 1481 (19.04.2003), 1597 (20.04.2005), 1660 (28.02.2006), 1837 (29.09.2008) and 1877 (07.07.2009) (David, 2012, p. 42).

This tribunal with temporary mandate has developed procedures to handle a large number of issues which include legal powers, facts, punishment and imprisonment (Mingst, 2008, p. 243). Unlike the Nurenberg and Tokyo Tribunals, the ICTY had to do with war crimes, especially with genocide, not with those crimes that threatened peace. It was authorized to judge the crimes committed in the wars that erupted as a result of interstate disputes in the former Yugoslavia and not the crimes 
committed during an international armed conflict that characterized the Nuremberg and Tokyo Tribunals. The ICTY had authority to prosecute and try individuals on four categories of offences: Grave breaches of the 1949 Geneva conventions, violations of the laws or customs of war, genocide and crimes against humanity. The ICTY had no authority to prosecute states for aggression or crimes against peace (these crimes are within the jurisdiction of the International Court of Justice).

Pursuant to Article 1 of the ICTY Statute, the Tribunal had jurisdiction over persons responsible for serious violations of international humanitarian law committed in the territory of the former Yugoslavia since 1991. The ICTY Statute also stated that the official position of an accused, whether as Head of State or Government or as a responsible Government official, does not relieved him of criminal responsibility nor mitigated the punishment. Articles 2 to 5 of the Statute identified four different categories of crimes mentioned above (Grave breaches of the 1949 Geneva conventions, violations of the laws or customs of war, genocide and crimes against humanity). Importantly, Article 7 provided that a person who planned, instigated, ordered, committed or otherwise aided and abetted in the planning, preparation or execution of a crime referred to in Articles 2 to 5 shall be individually responsible for the crime ("About the ICTY - Mandate and Crimes under ICTY Jurisdiction," n.d.).

\section{The organs of the icty}

Chambers were organized into three Trial Chambers and an Appeals Chamber, which were assisted in their work by the Chambers 
Legal Support teams. Those consisted of numerous legal staff, employed by the Registry that assisted the judges in conducting research, helped them in preparing and managing cases, as well as in participating in the draft of legal documents. Each Trial Chamber was composed of three permanent judges and a maximum of six ad litem judges which were appointed by the UN Secretary-General at the request of the President of the Tribunal. The Appeals Chamber consisted of seven permanent judges, five of whom were permanent judges of the ICTY and two of whom were permanent judges of the International Criminal Tribunal for Rwanda. The Tribunal's President and Vice-President were elected from among the ICTY judges. The President presided over all plenary meetings of the Tribunal, coordinated the work of the Chambers, supervised the activities of the Registry, and issued Practice Directions addressing detailed aspects of the conduct of proceedings before the Tribunal. The last President was Judge Carmel Agius from Malta who was appointed President of the Tribunal on November 17, 2015. His predecessors were: Theodor Meron (USA; 2003-2005 and 2011-2015); Patrick L. Robinson (Jamaica; 2008-2011); Fausto Pocar (Italy; 20052008); Claude Jorda (France; 1999-2002); Gabrielle Kirk McDonald (USA; 1997-1999); Antonio Cassese (Italy; 1993-1997) ("About the ICTY - Chambres," n.d.).

Registry in addition to the administration of the courtrooms, assumed duties that are often afforded to ministries in national systems. Finally, the Registry fulfilled the tasks of the administrative body of a UN organ. The offices of the Registry were responsible for bringing witnesses to testify in court, protecting them when necessary and 
providing them with expert psychological support. The Office of Legal Aid and Defense Matters ensured that all accused were duly represented. Its mission included assigning defense counsel to represent defendants who could not afford to pay their own counsel (indigent defendants). All court proceedings were interpreted and all documents used by the parties were translated into or from English, French, Bosnian/Croatian/Serbian, Albanian and Macedonian (“About the ICTY - Registry," n.d.).

Office of the Prosecutor was headed by a Prosecutor, who was appointed by the Security Council for a renewable four-year term. The Prosecutor was independent and does not seek or received instructions from external agencies such as any government or international organization, or from either of the Tribunal's other two organs. Pursuant to UN Security Council resolutions and the Tribunal's Statute, UN member-states were under an obligation to cooperate with the OTP's investigations and prosecutions. The job of the Prosecutor was twofold: to investigate crimes and to present cases at trial and later, if necessary, on appeal. Over the years, the focus of the OTP's work had shifted from investigations to prosecutions. The last Prosecutor was Serge Brammertz from Belgium, who was appointed on January 1, 2008. His predecessor was Carla Del Ponte from Switzerland (15 September 1999 to 31 December 2007). The first person appointed as ICTY Prosecutor was Ramon Escovar Salom from Venezuela (21 October 1993 to 3 February 1994), but he never took up the office. The first actual Prosecutor was Richard Goldstone from South Africa (15 August 1994 to 1 October 1996), followed by Louise Arbour from Canada (1 October 1996 to 15 September 1999) (“About the ICTY - Office of the Prosecutor,” n.d.). 
As of March 2016, the ICTY employed 425 staff members representing 69 nationalities ("The Cost of Justice," n.d.). The European Union supported this tribunal financially, but the main support has been to make pressure on the former Yugoslavian countries to arrest and transfer to the Hague their citizens, indicted for war crimes (Hoti \& Kosír, 2015, p. 146).

\section{The successes of the ICTY}

The prosecution of persons who were responsible for war crimes through the ICTY represents the most developed mechanism of transitional justice in the former Yugoslavia ("Transitional Justice in the Former Yugoslavia - Criminal prosecutions," n.d.). During its 24 years mandate, the ICTY has filed indictments against 161 persons for serious violations of international humanitarian law committed in the territory of the former Yugoslavia. The Tribunal issued its first indictment on November 7, 1994, against Dragan Nikolić, a commander of Sušica detention camp in eastern Bosnia and Herzegovina, for crimes committed against non-Serb civilians in 1992 ("Timeline - First indictment issued," 1994). On February 20, 2011, Goran Hadžić, former president of the self-proclaimed Serb republic within Croatia in the period 1992-1994, was arrested and completed the list of 161 persons indicted by the ICTY ("Timeline - Final fugitive arrested," 2011). Among these 161 indicted persons were: 101 Serbs, 37 Croats, 9 Bosniaks, 9 Kosovars, 2 Macedonians and 2 Montenegrins. With the exception of Biljana Plavšić (the former President of Republika Srpska, Bosnia and Herzegovina, pleads guilty to persecution of Bosnian 
Muslims, Bosnian Croats and other non-Serbs in 37 municipalities in Bosnia and Herzegovina from 1992 to 1995) who was the only accused female, all the accused were males.

On May 27, 1999, the ICTY issued an indictment and issued an arrest warrant for: Slobodan Milošević (the President of the Federal Republic of Yugoslavia), Milan Milutinović (the President of Serbia), Nikola Šainović (Deputy Prime Minister of the FRY), Dragoljub Ojdanić (Chief of Staff of the Yugoslav Army) and Vlajko Stojiljković (Minister of Internal Affairs of Serbia). These were the first indictments in the history of international criminal courts against state leaders. They were accused with murder [a crime against humanity, punishable under Article 5(a) of the Statute, and also a violation of the laws or customs of war, punishable under Article 3 of the Statute (namely a violation of Article 3 common to the 1949 Geneva Conventions)], persecutions on political, racial or religious grounds [a crime against humanity pursuant to Article 5(h) of the Statute the Tribunal] and deportation [a crime against humanity, punishable under Article 5(d) of the Statute of the Tribunal]. Specifically, the five indictees are charged with the murder of over 340 persons identified by name in an annex to the indictment ("Press President Milošević and Four other Senior Fry Officials Indicted for Murder, Persecution and Deportation in Kosovo," 1999).

The ICTY was the first international criminal tribunal to enter convictions for rape as a form of torture and for sexual enslavement as crime against humanity, as well as the first international tribunal based in Europe to pass convictions for rape as a crime against humanity, following a previous case adjudicated by the International Criminal 
Tribunal for Rwanda. The ICTY helped the survivors to talk about their suffering and to break the silence and the culture of impunity surrounding these terrible acts ("Crimes of Sexual Violence," n.d.). Since the Tribunal started its work, 78 individuals, or $48 \%$ of the 161 accused had charges of sexual violence included in their indictments. The ICTY exclusively began to deal with the trial of Dragoljub Kunarac, Radomir Kovač and Zoran Vuković who were the first accused persons of violence and sexual slavery on March 20, 2000 ("Press - The Trial of Kunarac, Kovač and Vuković will begin on Monday 20 March 2000," 2000).

Sentences to life imprisonment of the ICTY began on November 30, 2006 with Stanislav Galić, a former Bosnian Serb Army commander, for his role in the campaign of sniping and shelling against civilians in Sarajevo from September 1992 to August 1994 ("Press - Stanislav Galić sentenced to life imprisonment by Appeals Chamber for crimes committed during the siege of Sarajevo", 2006). The second life sentence was on July 10, 2009 against Milan Lukić, a Bosnian Serb convicted for the murder of more than 130 Bosnian Muslim civilians in Višegrad in 1992. He has been found guilty of persecutions, murder, extermination, cruel treatment, and inhumane acts, as crimes against humanity and war crimes, in relation to six discrete incidents ("Press - Milan Lukić and Sredoje Lukić Convicted of War Crimes in Višegrad," 2009). Ratko Mladić also known as "the Butcher of Bosnia", who was a former commander of the Bosnian Serb Army, was arrested on May 26, 2011 after evading arrest for 16 years. Charges against him included genocide, murder and persecutions, relating to Srebrenica, the siege of Sarajevo, 
and events in municipalities across much of Bosnia and Herzegovina. His trial began on May 16, 2012 ("Timeline - Ratko Mladić arrested," 2011). On November 22, 2017, in the final Trial Judgment of the ICTY, Trial Chamber I convicted Ratko Mladić to life imprisonment ("Timeline - Ratko Mladić sentenced to life imprisonment," 2017).

\section{The failures of the ICTY}

During the conflicts in the former Yugoslavia, over 140,000 people were killed and almost 4 million others were displaced. Of the 161 accused by the ICTY, only 89 of them have been sentenced, of which: 59 persons have served their sentence, 17 individuals were transferred to a State to serve their sentence, 9 persons died after trial or while serving their sentence and 4 persons are awaiting transfer to a State to serve their sentence. 18 persons have been acquitted (3 cases are being handle by the Mechanism for International Criminal Tribunals and 13 cases have been referred to national jurisdictions). 37 accused had their indictments withdrawn or died (20 persons had their indictments withdrawn, 10 accused are reported as having died before transfer to the ICTY and 7 accused died after transfer to the ICTY) (“Cases - Key Figures of the Cases", 2018).

Between 1 January and late May 1999, forces under the control of the Slobodan Milošević, Milan Milutinović, Nikola Šainović, Dragoljub Ojdanić and Vlajko Stojiljković persecuted the Kosovo Albanian civilian population on political, racial or religious grounds. By the date of the indictment, approximately 740,000 Albanians of Kosovo, about one-third of the entire Albanian population of Kosovo, had been 
expelled from Kosovo and thousands more are believed to be internally displaced. An unknown number of Albanians have been killed in the different operations by forces of the FRY and Serbia. However, the five accused were sentenced in this way: Proceedings against Slobodan Milošević terminated because he died in detention on March 11, 2006; Milan Milutinović acquitted on February 26, 2009; Nikola Šainović on January 23, 2014 was sentenced to 18 years in prison and on July 10, 2015 he was given early release; Dragoljub Ojdanić on February 26, 2009 was sentenced to 15 years in prison and on July 10, 2013 he was given early release; the proceedings against Vlajko Stojiljković terminated because he died on April 13, 2002 ("Case Information Sheet - Šainović et al.," n.d.).

According to statistics, which are constantly increasing, during the Bosnian War (1992-1995) victims of sexual violence were more than 50,000 people (women, girls, children and males) and more than 20,000 in the Kosovo War (1998-1999). Since the Tribunal started its work, 78 individuals or $48 \%$ of the 161 accused had charges of sexual violence included in their indictments. As of September 2016, only 32 individuals have been convicted for their responsibility for crimes of sexual violence, as defined under the first paragraph of the Article 7 (The first paragraph defines "A person who planned, instigated, ordered, committed or otherwise aided and abetted in the planning, preparation or execution of a crime referred to in articles 2 to 5 of the present Statute, shall be individually responsible for the crime) of the ICTY Statute. 4 of them were additionally convicted for failing to prevent or punish the actual perpetrators of the crimes, under the third paragraph of the Article 
7 (The fact that any of the acts referred to in articles 2 to 5 of the present Statute was committed by a subordinate does not relieve his superior of criminal responsibility if he knew or had reason to know that the subordinate was about to commit such acts or had done so and the superior failed to take the necessary and reasonable measures to prevent such acts or to punish the perpetrators thereof) of the Statute. The average of their sentence is 17 years in prison. There are 5 individuals who had their indictments withdrawn and 9 individuals died prior to the end of their trial or before their transfer to the Tribunal. 14 individuals are acquitted of sexual violence charges, 11 individuals are in ongoing proceedings and 6 individuals are referred to a national jurisdiction (“Crimes of Sexual Violence - In Numbers," n.d.).

The Srebrenica massacre is considered as the most horrible massacre in Europe after the Holocaust. The worst atrocity of the Bosnian war occurred in the summer of 1995 when the Bosnian town of Srebrenica, the declared safe area from the UN, was attacked by forces of the Bosnian Serb commander Ratko Mladić. From 11 to 13 July 1995 more than 8,000 Bosnian Muslim men and boys belonging to the ages of 12 to 77 were executed by Serb forces in an act of genocide and the rest of the town's women and children were expelled (Gruda, 2007, p. 691). For this massacre 20 individuals were indicted by the ICTY for crimes committed in Srebrenica in 1995. 14 persons were sentenced for genocide and for other crimes, 1 person was acquitted, 1 case terminated because the accused died before judgment and 4 accused are in ongoing proceedings ("About the ICTY - The Conflicts," n.d.). 


\section{The role of the international residual mechanism for criminal tribunals}

The International Residual Mechanism for Criminal Tribunals was established by UN Security Council Resolution 1966 on December 22, 2010 to complete the remaining work of the International Criminal Tribunal for Rwanda and the ICTY after the completion of their respective mandates. The Mechanism has two branches, one in Arusha, Tanzania and one in The Hague, Netherlands. During the initial years of the Mechanism's existence, it operated in parallel with the ICTR and the ICTY. Following the closure of the ICTR and the ICTY, the Mechanism operates as a stand-alone institution ("International Residual Mechanism for Criminal Tribunals - About," n.d).

Jovica Stanišić was the Head of the State Security Service of the Ministry of Internal Affairs of the Republic of Serbia and Franko Simatović was employed in the Second administration of this ministry. From or on about April 1, 1991 until December 31, 1995, they acting alone or in concert with members of the joint criminal enterprise, planned, ordered, committed or otherwise aided and abetted the planning, preparation or execution of persecutions of Croats, Bosnian Muslims and Bosnian Croats and other non-Serbs within the so-called "Serbian Autonomous Districts of Krajina and of Slavonia, Baranja and Western Srem" and territories in Bosnia and Herzegovina including the municipalities of Bijeljina, Bosanski Samac, Doboj, Mrkonjic Grad, Sanski Most and Zvornik ("Press - Jovica Stanisic and Franko Simatovic Indicted by the ICTY for Crimes Against Humanity and War Crimes," 2013). On December 15, 2015, the ICTY Appeals Chamber ordered that 
Stanišić and Simatović to be retried on all counts of the indictment and their trial commenced before the Mechanism on June 13, 2017 ("Cases Stanišić and Simatović," n.d.). Moreover, the case of Ratko Mladić is on appeal before the IRMCT.

Radovan Karadžić was President of the three-member Presidency of Republika Srpska from its creation in May 1992 until December 1992, and thereafter sole President of Republika Srpska and Supreme Commander of its armed forces until July 1996. He was convicted of genocide in the area of Srebrenica in 1995, of persecution, extermination, murder, deportation, inhumane acts, terror, unlawful attacks on civilians and hostage-taking ("Press - Tribunal convicts Radovan Karadžić for crimes in Bosnia and Herzegovina”, 2016). On July 22, 2016, the Prosecution and Radovan Karadžić file their notices of appeal before the IRMCT ("Cases - Radovan Karadžić Case - Key information \& Timeline," 2016). On March 20, 2019 the Appeals Chamber of the Mechanism, judges José Ricardo de Prada Solaesa and Ivo Nelson de Caires Batista Rosa set aside the sentence of 40 years of imprisonment and imposed on Radovan Karadžić a sentence of life imprisonment (“Cases - Karadžić, Radovan,” n.d.).

\section{Conclusion}

The decision of United Nations to establish the International Criminal Tribunal for the former Yugoslavia came as a result of bloody wars in the territory of the former Yugoslavia during the 1990s. This ad hoc tribunal prosecuted and arrested individuals in four criminal categories, which were serious violations of the Geneva Conventions of 
1949, violations of the laws or customs of war, genocide and crimes against humanity. During its mandate from 1993 to 2017, the ICTY was accompanied with successes and failures at the same time. The ICTY was the most developed mechanism of transitional justice in the former Yugoslav countries that has filed indictments against 161 persons. The biggest successes of the ICTY were the indictments and issuing arrests against state leaders, which were the first ones in the history of international criminal tribunals. The second success of this tribunal was the punishment of sexual rape as a form of torture and sexual enslavement as a crime against humanity. Then, the sentences with life imprisonments against Stanislav Galić, Milan Lukić and Ratko Mladić were other successes of the ICTY. However, the aforementioned successes of the ICTY can not hide its failures. From 161 accused, only 89 of them have been sentenced, 59 of whom have served their sentence. With the exception of two accused state leaders who died, one of them was acquitted and two others were granted early release. $48 \%$ of the 161 accused had charges of sexual violence in their indictments and only 36 of them were sentenced for that crime and the average of these sentences was 17 years in prison. For the genocide of Srebrenica, in which more than 8000 Bosniaks mainly men and boys were killed, and which is the most horrible massacre in Europe after the Holocaust, were sentenced only 14 individuals. The fact that the general characteristic of the international criminal justice is the presence of political impact cannot be denied, and immunity from the various political influences has not had either the ICTY. Although its mandate ended on December 31, 2017, unfortunately people in the former Yugoslav states, who were expelled from their countries, who are familiars of thousands of persons which 
were killed or disappeared, and who are victims of sexual violence, today can see the perpetrators of the above-mentioned crimes enjoying their freedoms.

\section{Bibliography}

- Ambos, K. (2013). Treatise on International Criminal Law, Volume I: Foundations and General Part. UK: Oxford University Press.

- Bantekas, I. \& Nash, S. (2009). International Criminal Law. 3d ed. London: Routledge.

- Cryer, R., Friman, H., Robinson, D. \& Wilmshurst, E. (2010). An Introduction to International Criminal Law and Procedure. $2^{\text {nd }}$ ed. UK: Cambridge University Press.

- David, E. (2012). Droit International Pénal. La Haye: Division de la codification du Bureau des affaires juridiques des Nations Unies.

- Gallant, K. (2009). The Principle of Legality in International and Comparative Criminal Law. UK: Cambridge University Press.

- Gruda, Z. (2007). Mbrojtja Ndërkombëtare e të Drejtave të Njeriut. Prishtinë: Universiteti Fama.

- Gruda, Z. (2013). E Drejta Ndërkombëtare Publike. Prishtinë: CIP.

- Hoti, A. \& Kosír, I., ed. (2015). European perspectives of the Western Balkans Countries I. Prishtina: AAB College.

- Hoti, A. \& Musliu, A. (2015). Parimi i Vetëvendosjes dhe Evoluimi i tij në të Drejtën Ndërkombëtare. Prishtinë: Kolegji Iliria.

- Mingst, A., K. (2008). Bazat e Marrëdhënieve Ndërkombëtare. Tiranë: Albanian Institute for International Studies.

- Radan, P. (2002). The Break-up of Yugoslavia and International Law. London: Routledge.

- Schabas, A., W. \& Bernaz, N., ed. (2011). Routledge Handbook of International Criminal Law. London: Routledge.

- Shaw, N., M. (2008). International Law. New York: Cambridge University Press. 


\section{The internet sources}

1. About the ICTY - Chambres. Retrieved January 29, 2019 from http://www.icty.org/en/about/chambers.

2. About the ICTY - Mandate and Crimes under ICTY Jurisdiction. $\begin{array}{llll}\text { Retrieved January } & 29, & 2019 & \text { from }\end{array}$ http://www.icty.org/en/about/tribunal/mandate-and-crimesunder-icty-jurisdiction.

3. About the ICTY - Office of the Prosecutor. Retrieved January 29, 2019 from http://www.icty.org/en/about/office-of-theprosecutor.

4. About the ICTY - Registry. Retrieved January 29, 2019 from http://www.icty.org/en/about/registry.

5. About the ICTY - The Conflicts. Retrieved January 31, 2019 http://www.icty.org/en/about/what-former-yugoslavia/conflicts.

6. About the ICTY - The Cost of Justice. Retrieved January 29, 2019 from http://www.icty.org/en/about/tribunal/the-cost-ofjustice.

7. Case Information Sheet - Šainović et al. Retrieved January 31, 2019 from http://www.icty.org/x/cases/milutinovic/cis/en/cis_sainovic_al_ en.pdf.

8. Cases - Karadžić, Radovan. Retrieved March 21, 2019 from http://www.irmct.org/en/cases/mict-13-55.

9. Cases - Key Figures of the Cases. Retrieved March 9, 2019 from http://www.icty.org/en/cases/key-figures-cases. 
10. Cases - Radovan Karadžić Case - Key information \& Timeline. (2016, July 12). Retrieved March 3, 2019 from http://www.icty.org/en/cases/radovan-karadzic-trial-keyinformation.

11. Cases - Stanišić and Simatović. Retrieved March 3, 2019 from http://www.irmct.org/en/cases/mict-15-96.

12. Crimes Against Humanity. Retrieved January 31, 2019 from https://www.un.org/en/genocideprevention/crimes-againsthumanity.shtml.

13. Crimes of Sexual Violence. Retrieved January 31, 2019 from http://www.icty.org/en/features/crimes-sexual-violence.

14. Crimes of Sexual Violence - In Numbers. Retrieved January 31, 2019 from http://www.icty.org/en/features/crimes-sexualviolence/in-numbers.

15. Genocide - Background. Retrieved January 31, 2019 from https://www.un.org/en/genocideprevention/genocide.shtml.

16. International Residual Mechanism for Criminal Tribunals About. Retrieved February 4, 2019 from http://www.irmct.org/en/about.

17. Press - Jovica Stanisic and Franko Simatovic Indicted by the ICTY for Crimes Against Humanity and War Crimes. (2003, May 6). Retrieved February 2, 2019 from http://www.icty.org/en/press/jovica-stanisic-and-frankosimatovic-indicted-icty-crimes-against-humanity-and-warcrimes.

18. Press - Milan Lukić and Sredoje Lukić Convicted of War Crimes in Višegrad. (2009, July 20). Retrieved January 31, 2019 from 
http://www.icty.org/en/press/milan-lukić-and-sredoje-lukićconvicted-war-crimes-višegrad.

19. Press - President Milošević and Four other Senior Fry Officials Indicted for Murder, Persecution and Deportation in Kosovo. (1999, May 27). Retrieved January 31, 2019 from http://www.icty.org/sid/7765.

20. Press - Stanislav Galić sentenced to life imprisonment by Appeals Chamber for crimes committed during the siege of Sarajevo. (2006, November 31). Retrieved January 31, 2019 from http://www.icty.org/en/press/stanislav-galić-sentencedlife-imprisonment-appeals-chamber-crimes-committed-duringsiege.

21. Press - The Trial of Kunarac, Kovač and Vuković will begin on Monday 20 March 2000. (2000, March 17). Retrieved February 2, 2019 from http://www.icty.org/en/press/trial-kunarac-kovacand-vukovic-will-begin-monday-20-march-2000.

22. Press - Tribunal convicts Radovan Karadžić for crimes in Bosnia and Herzegovina. (2016, March 24). Retrieved February 2, 2019 from http://www.icty.org/en/press/tribunal-convicts-radovankaradzic-for-crimes-in-bosnia-and-herzegovina.

23. Timeline - Final fugitive arrested. (2011, July 20). Retrieved February 2, 2019 from http://www.icty.org/en/features/timeline.

24. Timeline - First indictment issued. (1994, November 7). $\begin{array}{llll}\text { Retrieved } & \text { February } & 2, & 2019\end{array}$ http://www.icty.org/en/features/timeline.

25. Timeline - Ratko Mladić arrested. (2011, May 26). Retrieved February 2, 2019 from http://www.icty.org/en/features/timeline. 
26. Timeline - Ratko Mladić sentenced to life imprisonment. (2017, November 22). Retrieved February 2, 2019 from http://www.icty.org/en/features/timeline.

27. Transitional Justice in the Former Yugoslavia - Criminal prosecutions. Retrieved February 1, 2019 from https://www.ictj.org/sites/default/files/ICTJ-FormerYugoslaviaJustice-Facts-2009-English.pdf.

War Crimes - Elements of the Crime. Retrieved January 31, 2019 from https://www.un.org/en/genocideprevention/war-crimes.shtml 